\title{
LIG4 wt Allele
}

National Cancer Institute

\section{Source}

National Cancer Institute. LIG4 wt Allele. NCI Thesaurus. Code C50990.

Human LIG4 wild-type allele is located within 13q33-q34 and is approximately $11 \mathrm{~kb}$ in length. This allele, which encodes DNA ligase 4 protein, is involved in nonhomologous DNA end joining and in $V(D)$ J recombination. Defects in the gene produce allelic variants that are the cause of LIG4 syndrome. 